\title{
GIS Based Land Use Change Analysis of a Coastal Area of Bangladesh
}

\author{
Asikunnaby \\ Lecturer, Department of Disaster and Human Security Management \\ Bangladesh University of Professionals, Bangladesh \\ Mirpur, Dhaka-1216, Bangladesh \\ Tel: 88-02-8000368Ｅ-mail: asikunnaby@bup.edu.bd
}

Received: April 15, 2019 Accepted: May 13, 2019 Published: May 15, 2019

doi: 10.5296/jsss.v6i2.14784 URL: https://doi.org/10.5296/jsss.v6i2.14784

\begin{abstract}
Satkhira is a coastal district of Bangladesh where lives of millions of people are transforming due to natural hazards and anthropogenic stimuluses, specifically water bodies are facing the bulk of the transformation owing to salinity. The study area of this research includes part of Satkhira Sadar and the work is done based on Betna river influenced zone. Sundarban and the Bay of Bengal are close to this river and its highly influenced by saline water. The natural pristine environment of the area went through major changes during the last few decades, especially after the 1980's because of human interventions as well as natural causes. This research was an attempt to find out the transformations that took place in the area with remotely sensed imagery of 2018 and toposheet map of 1982, the underlying reasons of change and their consequences. The collected data were analyzed with Remote Sensing and Geographic Information System (GIS) software's for better interpretation and an in-depth understanding. Features which came into consideration frequently are river, shrimp farms, settlement, agriculture, embankment, salinity intrusion, increasing population, frequent hazard and riparian vegetation. The outcome of the work tells that the change in land use occurred mainly because of shrimp farming and salinity intrusion while Betna river took the major blow. Although economically beneficial, shrimp culture created a saline environment and modification of water bodies resulted in frequent waterlogging and escalated salinity in the area previously known as freshwater zone. While Bangladesh is scare in land resource, the coastal area such as the study site of this research is even more stressed owing to climate change and recurring natural hazards. Propositions are made at the end of the work to use the presented data and information mentioned in this study by corresponding authorities.
\end{abstract}


Keywords: Land use, Coastal area, Salinity, Shrimp farm, GIS

\section{Introduction}

Bangladesh has been gifted with rich natural resources. Its fertile land and climate allow the cultivation of a large variety of crops throughout the year (Hossain, 2001; Deb, 1998; Ahmed et al., 2008). Unfortunately, the resource base of the country is under tremendous pressure as the per capita available resources are very insignificant (Iftekhar et al., 2005; Hasan et al., 2013). Moreover, the ever-increasing needs and rising expectations of nearly 139 million people (BBS, 2011) make it difficult to keep its natural resources such as land, water and vegetation at a sustainable state (Ipe, 1995). The population of Bangladesh has increased swiftly during the last few eras (Rai et al., 2017). To meet the demand of the rising population, there has been encroachment upon forests and marginal lands (Nath et al., 2016). The wetlands have been reduced due to conversion into farmlands (Gordon et al., 2010) and recent prawn cultivation has also reduced forest and agricultural lands in the coastal districts of Bangladesh (Ali, 2006).

Bangladesh is a flood plain country with very low elevation (Haque, 2006); particularly the coastal communities frequently face storm surges and tropical cyclones resulting in loss of lives and property (Rakib et al., 2019; Nakashima et al., 2012; O'Brien et al., 2006). The major driving forces of land use change in Bangladesh are increasing population, rapid urbanization and climate change (Grimm et al., 2008; Dewan \& Yamaguchi, 2009; Dale, 1997). Unplanned and irrational use of land reduces the quantity and quality of available land resources. The examples of such irrational uses are unintended construction of physical infrastructure like roads, polders, barrages etc., expansion of urban areas, consequent engulfing of agricultural land, hill cutting, unplanned shrimp culture, filling of rivers and water bodies (Islam et al., 2005; Sayeed, 2013; Hassan et al., 2016). The resource base, especially the land resources are in a fragile condition. Cropped land-man ratio for Bangladesh is 0.06 hectares (ha) per person which is not a significant number (Parvin et al., 2017). Total agricultural land area is 14.85 million hectares (ha) where cultivable land is 8.44 million hectare and total cropped area is 13.74 million hectares (Quasem, 2011). Because of increasing population more lands are continually occupied by settlement \& construction of infrastructure; this process reduces the size of agricultural land in Bangladesh (Chaudhuri \& Mishra, 2016; Hasan et al., 2017). Soil Resources Development Institute (SRDI) estimated land transfer from agriculture to non-agriculture sector using aerial photographs \& Landsat imageries to approximately $0.13 \%$ per year during the period 1963 to 1983 (SRDI, 2010). Considering the small amount of arable land and crop production, worryingly agricultural land is transferred to non-agricultural land by $1 \%$ every year in Bangladesh (SRDI, 2013).

Satkhira region is one of the important parts of our country for its resources and unique ecosystem. Though, Satkhira Sadar had a pristine environment in the 1980's the study area went through major changes of land use and land cover in the last few decades (Barai et al., 2019; Khan et al., 2015). The pursuit of any policy regarding land and environment is a necessity to explore the present situation of land use pattern, its trend, nature of dependency on land, land management scenario in terms of its records, maps and maintaining database. 


\section{Macrothink}

The study aims to document the nature of land transformation in the coastal area of Bangladesh and identify its drivers. This research considered 1982 as the baseline year and tried to compare the changes up to 2018. The objectives of the study were to explore the extent of land use transformation, causes of change and consequences that local people face due to that transformation.

\section{Study Area}

The study area covers an area of 12 square kilometers which is on an average 14 feet high from sea level meaning it's a low floodplain area. Betna River flows from north-west to south east across the middle of the study area with a length of 5 kilometers. The river defines the basin at it's east with low elevation and marginally high grounds at western part. Physically the research site is located 16 kilometers away from the Sundarban and 90 kilometers from the Bay of Bengal in Bangladesh. Satkhira Sadar reside in an area of 400.82 square km, which is circumscribed by Kalaroa upazila on the north, Debhata and Assasuni upazilas on the south, Tala upazila on the east and West Bengal of India on the west.

The study area is located between $22^{\circ} 41^{\prime} 30^{\prime \prime}$ and $22^{\circ} 43^{\prime} 30^{\prime \prime}$ north latitude and from $89^{\circ} 06^{\prime} 00^{\prime \prime}$ to $89^{\circ} 08^{\prime} 00^{\prime \prime}$ east longitudes. The area is $27.84 \mathrm{sq} \mathrm{km}$ and owns a population of 344444 ; population density per sq $\mathrm{km} 859$ persons. It has a rapid growing population and has experienced a change in its traditional agrarian and fisheries land use during the last few decades (Banglapedia, 2012).

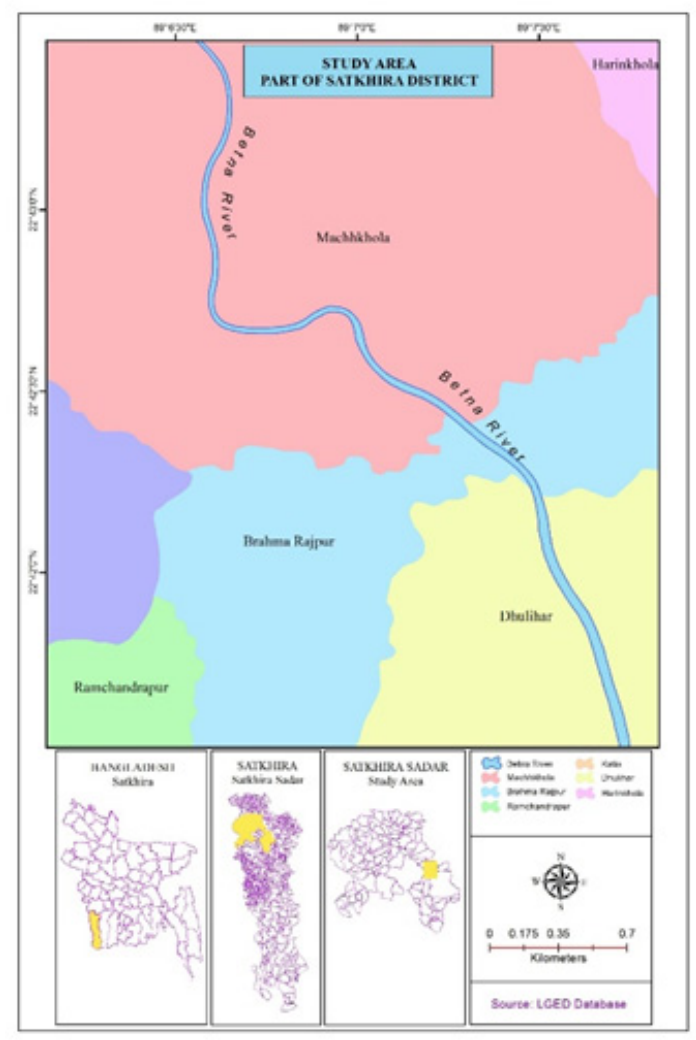

Figure 1. Map of the study area (Source: prepared by author) 


\section{Data and Methods}

Both primary and secondary data were used to conduct this research work. An extensive literature review has been done in search of relevant secondary data. Different books and reports containing the land use data with associated maps and other information's were collected from numerous published sources such as Bangladesh Bureau of Statistics (BBS), Soil Resource Development Institute (SRDI), Local Government Engineering Department (LGED) and Center for Environmental and Geographical Information Services (CEGIS). Topographic map of scale 1:50000 of the study area was collected from the Department of Geography and Environment of Jahangirnagar University, Bangladesh through the researcher's supervisor. The number of the sheet was 79 F/2 of the year 1982 from Survey of Bangladesh (Third Edition Printing). In this study, a smaller portion of the toposheet was used by referencing it for further uses in GIS and other analysis at representation levels. Furthermore, Bangladesh Population Census and mouza level data were helpful to construct the general understanding of the study area. In conjunction with this, Soil Resource Development Institute (SRDI) report and Local Government Engineering Department's (LGED) detailed upazila base maps were used for mapping spatial distribution of geographic features with the help of GIS techniques.

Primary data were collected through 3 Focus Group Discussions (12 to 15 members per group), 5 Key Informant Interviews and Matrix Ranking (PRA tool) from the study area. Besides, Geographic Information System (GIS) has been adopted for mapping the land use changes from 1982 to 2018. After the collection of raw hard copy maps from different published sources the researcher scanned the maps and then digitized them to convert into a usable format for the 1982 data reference. The satellite image of 2018 for the study area was collected from United States Geological Survey's (USGS) EarthExplorer platform. The analysis of the 1982 map and 2018 image for the research has revealed the spatial distribution of physical and social features of the study area. The primary data sources were used to understand the causes and consequences of land use change while secondary sources helped to build databases and prepare maps of the different land features.

\section{Results and Discussion}

Satkhira Sadar area experienced some dramatic changes in land use in the last forty years (Islam et al., 2018). This draws attention for a specific research to find out the reasons behind these changes, its extent and impact on the research area. Typical land use mapping methods are time consuming and requires a lot of effort and the outputs become invalid within a short span of time due to the dynamic changes of a country like Bangladesh. The attempt was to map the existing and previous conditions for examining the changes and their reason.

\subsection{Land Use of 1982}

The toposheet of the study area from 1982 was used as the base map for the analysis and interpretation of land use. Assistance from the researcher's supervisor and review of books, journals, articles helped in defining the land use types for the area. The research utilized the Soil Resource Development Institute's (SRDI) records as a source as they store data on soil, 


\section{Macrothink}

environment and crop production of Bangladesh. The SRDI is an administration association under the regulatory control of the Ministry of Agriculture, Bangladesh and intends to ensure food security through sustainable agriculture.

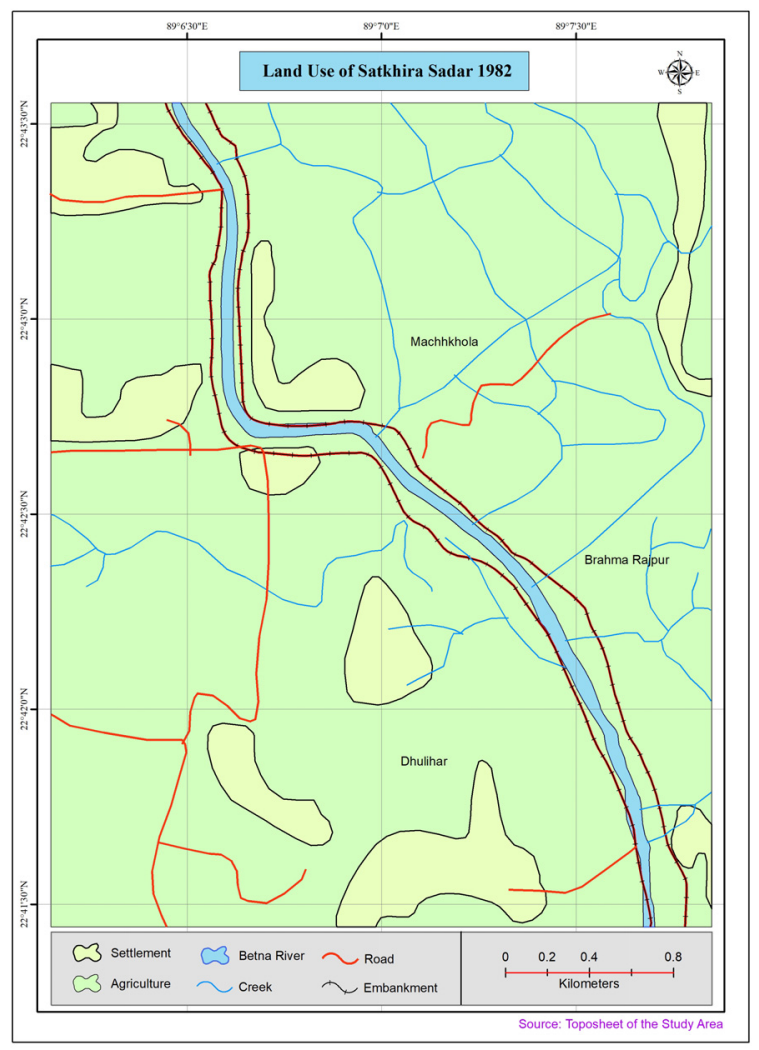

Figure 2. Land Use of 1982 (Source: prepared by author)

From the data analysis and produced map the area shows mainly three land features including agricultural land, settlements and Betna river. The river in the study area is encircled by embankment although the streams are free from enclosure and there were presence of roads as means of communication during 1982. The study area was taken, keeping the Betna river in mind for the freshwater zone and small parts around that river. The site extent was calculated by ArcGIS 10.3 software with BTM projection in a few units. From figure 2 its visible that the largest proportion is covered by agricultural practice $(9.7 \mathrm{sq} . \mathrm{km}, 85 \%)$, after that settlement occupies $1.35 \mathrm{sq}$. km. and small portions from Betna river, creek, road, embankment combines to a total area of $11.32 \mathrm{sq} . \mathrm{km}$.

\subsection{Land Use of 2018}

During the analysis of the satellite image for land use the author followed standard classification systems and customized it according to the needs and available features of the study area (Anderson et al., 1976; Pandy \& Nathawat, 2006; Foley et al., 2005). In a span of 36 years, the uses of different technologies, necessity of extra food, scarcity of living place added a great momentum to land use change (Figure 3). Recognizing the reasons for land use 


\section{Macrothink}

change requires understanding of both how individuals make choices and how explicitly ecological and social variables interface to impact these choices. Land use choices are made and affected by natural and social factors over a wide scope of spatial scales, from household unit level choices that impact nearby land use practices to arrangements and policies that can modify land use regionally and even worldwide. As a result, the author had to bring in some new land use classes like- shrimp farm, marsh area and riparian area. Among all, shrimp occupies largest entity, which will be prominently visible from Figure 3.

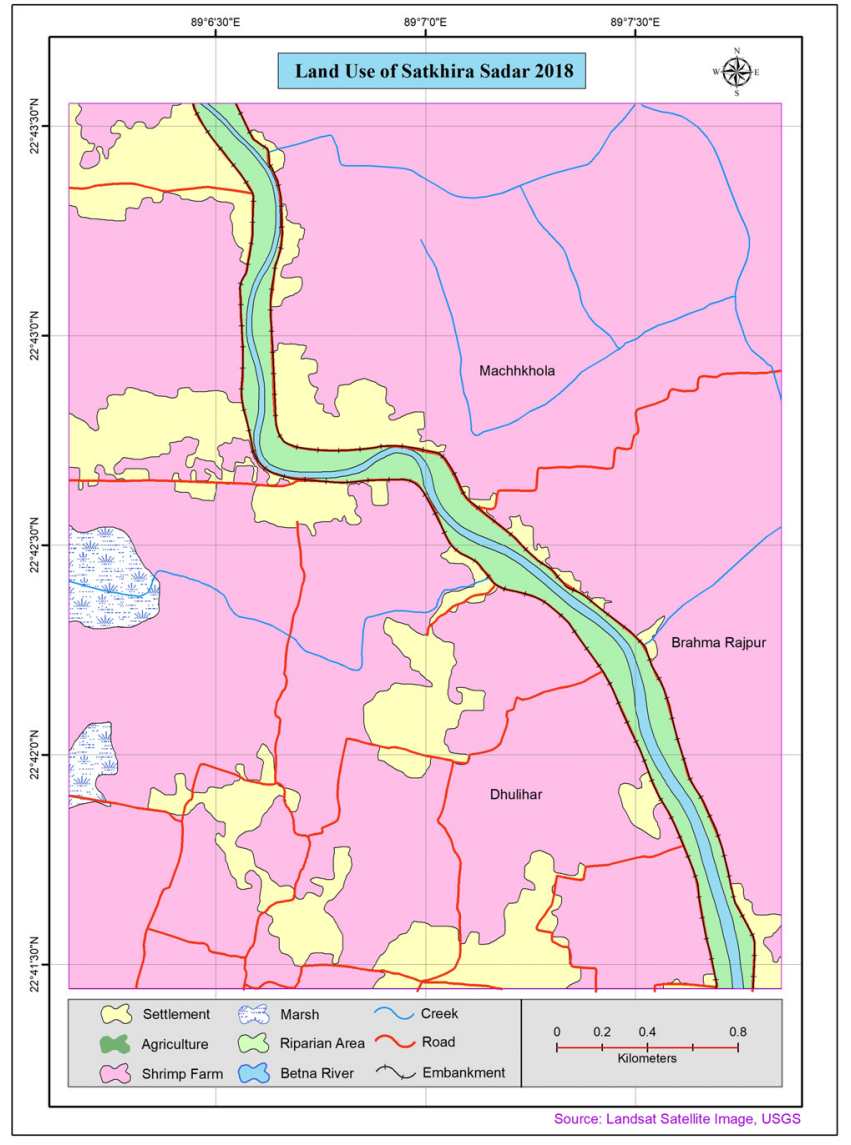

Figure 3. Land Use of 2018 (Source: prepared by author)

The biggest portion of land use goes under shrimp farming with 8.86 sq. km., settlements occupies 1.59 sq. km. and Betna river, riparian area, marsh, embankment, road, creek constitutes the rest 0.97 sq. $\mathrm{km}$. Most of the agricultural land converted into shrimp farming and settlement structures. The pristine nature of land with grazing areas are not available any more. The road infrastructures developed, and marsh area emerged in the south-western part of the riparian area along the river line (shrub vegetation), only few homestead vegetation was visible which was overlooked.

\subsection{Extent of Change and Their Causes}

The land use changes were plotted in a cross table which gives a comprehensive way of 
interpretation and presents all the parameters in a diagnostic manner. The cross table (table 1) depicts feature specific changes in land use between 1982 base map and 2018 map. Agriculture from 1982 converted into settlement, shrimp farm, marsh area, river and riparian area covering an area of 5.71 square kilometers in total. Betna River turned into shrimp farm, settlement and riparian area of 4.27 square kilometers. Moreover, agriculture, riparian area and Betna river amounts to 1.36 square kilometers.

Table 1. Cross table of the land use features

\begin{tabular}{lllll}
\hline Features & Agriculture & Betna River & Settlement & Grand Total \\
\hline Agriculture & 0.013 & - & 0.095 & 0.108 \\
Betna River & 0.192 & 0.218 & 0.003 & 0.414 \\
Marsh & 0.958 & - & - & 0.958 \\
Riparian Area & 0.009 & 3.898 & 0.004 & 3.911 \\
Settlement & 3.511 & 0.07 & 0.75 & 4.333 \\
Shrimp Farm & 1.033 & 0.091 & 0.288 & 1.413 \\
Grand Total & 5.718 & 4.278 & 1.142 & 11.139 \\
\hline
\end{tabular}

Note: Columns denote 1982 and rows denote 2018.

Human interference in the river mostly changed the land use pattern, people involved themselves in shrimp farming for large margin benefits, resulting the alteration of land use during the last thirty-six years. Local inhabitants control the flow of water in the river with sluice gates and embankment, whenever needed water is taken into lands through canals, this cause the saline water from the Bay of Bengal to rise upwards into high grounds as they are being congested in the downstream terrestrial areas. Satkhira Sadar went through some major changes in terms of land cover and land use for a few factors: the rise of population every year, necessity of settlement, economic activities and interference with the natural flowing water bodies for further increase in production, improper management and lack of planning contributes in these processes at various proportions. The large embankment built around river edges for the protection of the low-lying areas triggers a lot of factors. The purpose is to keep the lands available for intensive agriculture, non-flooded settlement and infrastructures, but uncontrolled management after the building of embankment impacts on natural siltation procedure for high level of productivity every year with fertile soil.

All ecosystems are interrupted as water can't enter the lower grounds and mainly upsetting wetland ecosystems. These systems run complexly with interconnections among every component. The lives of animals depending on vegetative systems and water bodies will go through a hard time in near future. Interference from indigenous people in an unplanned manner will harshly impact the local ecosystem. Because of long range results, people are 
less concerned about the facts yet to occur. The amount of saline in the area is still in a moderate stage comparing the downstream conditions of our country. The embankment blocks the natural flow of water from tides and help them go further upward day by day, as a result higher grounds are also getting saline. The shrimp farming started in the locality in the late 1980's and it is still rising. The vegetation types and species are adapting with changed environmental set of parameters, some are being extinct and new groups are evolving with salinity tolerant capabilities.

The following table was generated from primary data (matrix ranking) that represent the local people's perspective about land use changes and the reasons behind. The researcher identified four major drivers of change among which shrimp farming is the prominent one. Shrimp farms are still on the rise in the locality and it's been same since the 1980's. Salinity intrusion and increasing population were identified as 2 nd and 3rd prioritized drivers both of which supports shrimp farming in terms of income generating option and optimum condition for shrimps. However, the consequences of shrimp farming are extreme; it degrades the quality of land and minimizes cultivability of any crop. If one farmer decides to go back to traditional agriculture from shrimp farming he/she must take a few years break in cultivation so that the fertility of the land recovers and sometimes a land never recovers. Frequent hazards were the number four in their ranking which not only drives land use change by increasing salinity (cyclone, flood etc.) in the locality, but also drives people out the area and people are forced to migrate or change their previous profession to adapt within the newer environmental settings.

Table 2. Drivers of land use change and their reason

\begin{tabular}{lll}
\hline Drivers of change & Reason \\
\hline $\mathbf{2}$ & Shrimp farm & $\begin{array}{l}\text { High profit compared to other sources of income } \\
\text { and increasing saline environment supports shrimp } \\
\text { farming. }\end{array}$ \\
& $\begin{array}{l}\text { Polders in the coastal area, repetitive waterlogging, } \\
\text { decreasing fresh water flow from the upstream } \\
\text { rivers, sea level rise contribute to salinity intrusion. }\end{array}$ \\
& Increasing population & $\begin{array}{l}\text { Growing population and mounting need of } \\
\text { infrastructural development, rising number of } \\
\text { mouths to feed contributes to rapid land use } \\
\text { change. }\end{array}$ \\
& Frequent hazard & $\begin{array}{l}\text { Cyclone, storm surge, tidal flood and other costal } \\
\text { hazards test the strength of local people and they } \\
\text { are forced to change uses of available land as an } \\
\text { adaptation option. }\end{array}$ \\
\hline
\end{tabular}


Land resource is scarce in Bangladesh, while coastal areas face impacts of climate change and natural hazards which not only adds to the existing pressure but also threatens socio-economic sustainability (Reuveny, 2007; Shamsuddoha \& Chowdhury, 2007). The increments in population directly impacted the land use of the study area. People are bound to make choices of converting agricultural lands into shrimp farms for greater profit, building newer settlements and even migrate if livelihoods are stressed as an adaptation option (Ali, 2006). These phenomena are visible in urban, peri-urban and hinterland areas.

Land use changes are significantly driven by institutions such as political, economic and local administration. Degradation of land quality and environmental consequences can be attributed to weak institutional framework, lack of implementation of the existing policies and poor coordination among stakeholders. It is therefore critical that all possible managers participate in the decision making and application phases to ensure sustainable land use in the coastal area of Bangladesh.

\section{Conclusion}

Human intervention and environmental processes drive land use change simultaneously, although the patterns of change are repeated if one analyses the time series of a specific place. River area decreased from the earlier documentations as they passed into infrastructures and shrimp farming. Although the amount is minimum, some agricultural practices are available in the study area. Vegetation cover changed alarmingly throughout the area from their natural state of 1980's. Infrastructural development like- roads, settlements have increased for better communication and necessity for rising population. Shrimp farming occupied the area for the ambition of higher economic benefits and convenient conditions. Farming of shrimp with rising benefits tempts people for changing the natural state of the environment, blocking natural water flow, building of sluice gates, cutting of unplanned canals and clearing of vegetation.

This study included an approach of GIS and Remote Sensing towards finding the changes of land use for part of Satkhira Sadar area. The amount of land use changed predominantly for shrimp farming and mismanagement of embankment and sluice gates, cutting of canals in an unplanned manner, shifting ecosystem, soil salinity, less productivity of agricultural lands requires attention of respective authorities. The changes are going thick and fast recently compared to previous decades. Sustainable development is now a worldwide word of popularity, Bangladesh is not excluded from that perception. This cannot take place without steps for awareness among the people living in the area in terms of ecosystem conservation, proper management of the embankment, making policies in relation with the local community and planning insights from experts. All the above marked tasks need precise database of land use; their monitoring from time to time with the help of Geographic Information System (GIS) and Remote Sensing in an inclusive manner with supportive detailed research.

\section{References}

Ahmed, N., Demaine, H., \& Muir, J. F. (2008). Freshwater prawn farming in Bangladesh: 
history, present status and future prospects. Aquaculture Research, 39(8), 806-819. https://doi.org/10.1111/j.1365-2109.2008.01931.x

Ali, A. M. S. (2006). Rice to shrimp: Land use/land cover changes and soil degradation in Southwestern Bangladesh. Land Use Policy, 23(4), 421-435. https://doi.org/10.1016/j.landusepol.2005.02.001

Anderson, J. R. (1976). A land use and land cover classification system for use with remote sensor data (Vol. 964). US Government Printing Office. https://doi.org/10.3133/pp964

Banglapedia (2012). National Encyclopedia of Bangladesh, Asiatic society of Bangladesh, publishing Co. 1td. Dhaka, 1000. Bangladesh.

BBS (2011). Bangladesh Bureau of Statistics (BBS). Peoples Republic of Bangladesh, Dhaka, Bangladesh.

Barai, K. R., Harashina, K., Satta, N., \& Annaka, T. (2019). Comparative analysis of land-use pattern and socioeconomic status between shrimp-and rice-production areas in southwestern coastal Bangladesh: a land-use/cover change analysis over 30 years. Journal of Coastal Conservation, 1-12. https://doi.org/10.1007/s11852-019-00682-2

Chaudhuri, G., \& Mishra, N. B. (2016). Spatio-temporal dynamics of land cover and land surface temperature in Ganges-Brahmaputra delta: A comparative analysis between India and Bangladesh. Applied Geography, 68, 68-83. https://doi.org/10.1016/j.apgeog.2016.01.002

Dale, V. H. (1997). The relationship between land - use change and climate change.

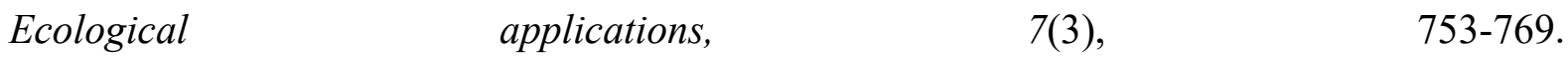
https://doi.org/10.1890/1051-0761(1997)007[0753:TRBLUC]2.0.CO;2

Deb, A. K. (1998). Fake blue revolution: environmental and socio-economic impacts of shrimp culture in the coastal areas of Bangladesh. Ocean \& Coastal Management, 41(1), 63-88. https://doi.org/10.1016/S0964-5691(98)00074-X

Dewan, A. M., \& Yamaguchi, Y. (2009). Land use and land cover change in Greater Dhaka, Bangladesh: Using remote sensing to promote sustainable urbanization. Applied geography, 29(3), 390-401. https://doi.org/10.1016/j.apgeog.2008.12.005

Foley, J. A., DeFries, R., Asner, G. P., Barford, C., Bonan, G., Carpenter, S. R., ... Helkowski, J. H. (2005). Global consequences of land use. science, 309(5734), 570-574. https://doi.org/10.1126/science. 1111772

Gordon, L. J., Finlayson, C. M., \& Falkenmark, M. (2010). Managing water in agriculture for food production and other ecosystem services. Agricultural Water Management, 97(4), 512-519. https://doi.org/10.1016/j.agwat.2009.03.017

Grimm, N. B., Faeth, S. H., Golubiewski, N. E., Redman, C. L., Wu, J., Bai, X., \& Briggs, J. M. (2008). Global change and the ecology of cities. science, 319(5864), 756-760. https://doi.org/10.1126/science. 1150195

Haque, S. A. (2006). Salinity problems and crop production in coastal regions of Bangladesh. 
Pakistan Journal of Botany, 38(5), 1359-1365.

Hasan, M. N., Hossain, M. S., Islam, M. R., Bari, M. A., Karim, D., \& Rahman, M. Z. (2013). Trends in the availability of agricultural land in Bangladesh. Soil Resource Development Institute (SRDI), Ministry of Agriculture, Bangladesh, Dhaka.

Hasan, S., Deng, X., Li, Z., \& Chen, D. (2017). Projections of future land use in Bangladesh under the background of baseline, ecological protection and economic development. Sustainability, 9(4), 505. https://doi.org/10.3390/su9040505

Hassan, M. M., \& Nazem, M. N. I. (2016). Examination of land use/land cover changes, urban growth dynamics, and environmental sustainability in Chittagong city, Bangladesh. Environment, development and sustainability, 18(3), 697-716. https://doi.org/10.1007/s10668-015-9672-8

Hossain, M. K. (2001). Overview of the forest biodiversity in Bangladesh. Assessment, conservation and sustainable use of forest biodiversity, 33-35.

Iftekhar, M. S., \& Hoque, A. K. F. (2005). Causes of forest encroachment: An analysis of Bangladesh. GeoJournal, 62(1-2), 95-106. https://doi.org/10.1007/s10708-005-7917-z

Ipe, C. V. (1995). Issues in the management of the environment and natural resources in Bangladesh. Journal of Environmental Management, 45(4), 319-332. https://doi.org/10.1006/jema.1995.0079

Islam, M. R., Abdullah, H. M., Ahmed, Z. U., Islam, I., Ferdush, J., Miah, M. G., \& Miah, M. M. U. (2018). Monitoring the spatiotemporal dynamics of waterlogged area in southwestern Bangladesh using time series Landsat imagery. Remote Sensing Applications: Society and Environment, 9, 52-59. https://doi.org/10.1016/j.rsase.2017.11.005

Islam, M. S., \& Wahab, M. A. (2005). A review on the present status and management of mangrove wetland habitat resources in Bangladesh with emphasis on mangrove fisheries and aquaculture. In Aquatic biodiversity II (pp. 165-190). Springer, Dordrecht. https://doi.org/10.1007/1-4020-4111-X_19

Khan, M. M. H., Bryceson, I., Kolivras, K. N., Faruque, F., Rahman, M. M., \& Haque, U. (2015). Natural disasters and land-use/land-cover change in the southwest coastal areas of Bangladesh. Regional Environmental Change, 15(2), 241-250. https://doi.org/10.1007/s10113-014-0642-8

Nakashima, D., McLean, K. G., Thulstrup, H., Castillo, A. R., \& Rubis, J. (2012). Weathering Uncertainty: Traditional Knowledge for Climate Change Assessment and Adaptation (Paris, Darwin).

Nath, T. K., Jashimuddin, M., \& Inoue, M. (2016). Community-based forest management (CBFM) in Bangladesh (Vol. 22). Switzerland: Springer. https://doi.org/10.1007/978-3-319-42387-6

O'Brien, G., O'Keefe, P., Rose, J., \& Wisner, B. (2006). Climate change and disaster 
management. Disasters, 30(1), 64-80. https://doi.org/10.1111/j.1467-9523.2006.00307.x

Pandy, A. C., \& Nathawat, M. S. (2006). Land Use Land Cover Mapping Through Digital Image Processing of Satellite Data-A case study from Panchkula. Ambala and Yamunanagar Districts, Haryana State, India.

Parvin, G. A., Ali, M. H., Fujita, K., Abedin, M. A., Habiba, U., \& Shaw, R. (2017). Land use change in southwestern coastal Bangladesh: Consequence to food and water supply. In Land use management in disaster risk reduction (pp. 381-401). Springer, Tokyo. https://doi.org/10.1007/978-4-431-56442-3_20

Rai, R., Zhang, Y., Paudel, B., Li, S., \& Khanal, N. (2017). A synthesis of studies on land use and land cover dynamics during 1930-2015 in Bangladesh. Sustainability, 9(10), 1866. https://doi.org/10.3390/su9101866

Rakib, M. A., Sasaki, J., Pal, S., Newaz, M. A., Bodrud-Doza, M., \& Bhuiyan, M. A. (2019). An investigation of coastal vulnerability and internal consistency of local perceptions under climate change risk in the southwest part of Bangladesh. Journal of environmental management, 231, 419-428. https://doi.org/10.1016/j.jenvman.2018.10.054

Reuveny, R. (2007). Climate change-induced migration and violent conflict. Political geography, 26(6), 656-673. https://doi.org/10.1016/j.polgeo.2007.05.001

Sayeed, A. (2013). Causes and Consequences of Land Degradation: Conversion of Agricultural land to Non-Agricultural usages in Bangladesh: A case study on 'Keyain'village of Munshigonj District.

Shamsuddoha, M., \& Chowdhury, R. K. (2007). Climate change impact and disaster vulnerabilities in the coastal areas of Bangladesh. COAST Trust, Dhaka.

SRDI (2013). Agricultural land availability in Bangladesh. Soil Resource Development Institute (SRDI), Ministry of Agriculture, Government of the People's Republic of Bangladesh.

Quasem, M. A. (2011). Conversion of Agricultural Land to Non-agricultural Uses in Bangladesh: Extent and Determinants. Bangladesh Development Studies, Vol. XXXIV, 59-85.

\section{Copyright Disclaimer}

Copyright for this article is retained by the author(s), with first publication rights granted to the journal.

This is an open-access article distributed under the terms and conditions of the Creative Commons Attribution license (http://creativecommons.org/licenses/by/3.0/). 